\title{
SUBALTERNITY IN AMITAV GHOSH'S SEA OF POPPIES: REPRESENTATION OF INDIAN WOMEN'S STRUGGLE AGAINST PATRIARCHY
}

\author{
a Sophia Kiki Artanti, b Mamik Tri Wedati \\ ${ }^{a, b}$ English Literature, Faculty of Language and Arts, State University of Surabaya \\ e-mail: sophiaartanti@mhs.unesa.ac.id
}

\begin{abstract}
This study analyses the subaltern that represented by Deeti in Amitav Ghosh's Sea of Poppies. The subject of the subaltern as an Indian woman is struggling against patriarchy in society. This study uses the postcolonialism theory, including the theory of subaltern to analyze the representation of the subaltern subject who fights against patriarchy. That subject represented by Indian women as the subject of the subaltern. The narration of Deeti in the first Trilogy Sea of Poppies by Amitav Ghosh is the main focus of this study. This study using postcolonialism theory from Homi K. Bhabha and Gayatri Chakravorty Spivak, then subaltern theory also using Gayatri Chakravorty Spivak which describes how 'colonialized subject' lives and theories from Sylvia Walby and Gerda Lerner for the definition of patriarchy. So, this study mainly about how patriarchy will be related to Deeti as the subaltern explained by Gayatri Chakravorty Spivak. The data will be taken from many aspects such as dialogues, a depiction of the situation, characters, etc. This study analyzed two problems, which are (1) How is subalternity represented in Amitav Ghosh's Sea of Poppies? (2) How do Indian Women's struggle to fight against patriarchy in Sea of Poppies by Amitav Ghosh? The results of this study show that Subaltern represented by Indian Women. Then the struggle of Deeti as an Indian Woman and the other characters fights against the patriarchy.
\end{abstract}

Keywords: Patriarki, Poskolonialisme, Subaltern. 


\section{INTRODUCTION}

Postcolonialism is the study of cultural legacy about colonialism and imperialism. The main focus of this study is the human consequences of control and exploitation of colonized the people and their lands. Yet the term continues to be used from time to time to mean simply 'anti-colonial' and to be synonymous with 'postindependence', as in references to the 'post-colonial state'. In actual postcolonialism has to be understood only about colonialism, myth and history, language and landscape, self and other are all very important ingredients of postcolonial studies. It means that the physical area of postcolonial study is wider than any other discipline in literature. Moreover, Spivak mentioned in her critical theory about post-colonial in In Other Worlds: Essays in Cultural Politics (1987) deserves special mention including the essay 'Can the Subaltern Speak?' She widened the scope of subaltern literature including the works of literature of marginalized women. She makes a harsh comment on the male dominant society and shows the secondary position, inferior role given to women in patriarchy.

According to Spivak, women are underrated and underestimated to men in postcolonial literature. Spivak uses a subaltern to denote the lower rank and marginal status of women in society (Sawant, 2015:4). Gayatri Chakravorty Spivak told through her book "Can the Subaltern Speak" that rules, laws, and culture in society control the oppress of women in any aspect (Jouzaee, 2014:1525). The domination of men leads the women to obey them plus society makes the men be a leader in aspect in society. Patriarchy is lead to discrimination or devaluation against women. According to Simon De Beauvoir, femininity is not inborn but it is created by society to make women in a lower position than men (Tyagi, Pradesh, \& Pradesh, 2018b). The result is women will have anxiety, helpless identity, and a revolutionary attitude in a patriarchal society.

Sea of poppies is the first volume of Ibis Trilogy that contains about historical fiction which is set in the 19th century. It deals with the trade of opium among India and China run by The East India Company and the trafficking of coolies to Mauritius. Then this comprises three books, there are Sea of Poppies (2008), River of Smoke (2011), and Flood of Fire (2015). This novel tells about political, traditional, and cultural by Indians in Calcutta. Amitav wrote this novel from his insight and connection with the phenomenon. Through small historical narration, he shows the socio-cultural changes that take place within two or three decades.

The first story in this novel tells about Deeti as the main women characters. Deeti was a poor woman married with Hukam Singh, a rich man from high strata in their society. In Hukam's family Deeti was raped by her brother-in-law, Chandan Singh and had a daughter called Kabutri. Her mother-in-law and her uncle Bhyro Singh were never love her properly. They tortured and mocked her every time. Then Deeti decided to burn herself with the late Hukam Singh in Sati. Unfortunately, she saved by Kalua, Hukam Singh's driver and then they escaped together to the ship namely Ibis. They became immigrants in there and met other people who had the same faith like them. Patriarchy is also occurred in Ibis and Deeti was still became the subaltern subject, but she through that things with her friends. When Bhyro Singh found her and Kalua, they escaped from Ibis with their friends.

Thus, this study will focus on the representation of the subaltern that will be presented by Deeti as Indian women and the main character in this novel. Deeti is being objectified by men in the first step of her life, then she is saved by Kalua that becomes her second husband. Then she gets a new identity as Aditi and fights for her life. Deeti is the symbol of the subaltern subject who struggles in a patriarchal society 
that assumes women are dominated by men. Hence, to be able to know how the subaltern is being affected by the patriarchy through Deeti as the representation of the subaltern itself, this study must be connected to the relationship between subaltern and patriarchy. Amitav Ghosh as the author has a representation of the connection between Deeti's life and the society in the novel Sea of Poppies.

\section{METHODS}

The data source in this study is mainly in the novel by Amitav Ghosh Sea of Poppies. The analysis of the study will be taken from the quotations, dialogues, and descriptions from the novel. Those analyses will be added by some explanation from some experts. Then data collection will be concluded on Deeti either some characters who influence Deeti's life or the opposite. Those characters will be analyzed into this thesis by using some theories by the experts.

The main approach is taken from postcolonialism theory by Homi K. Bhabha and Gayatri Chakravorty Spivak and then combined with subaltern theory by Gayatri Chakravorty Spivak. To explain the circumstances of the main character and others, this study will be discussed the theory of the patriarchal system by Sylvia Walby. In the next step, this study will be explained how Deeti's life in her family husband as the subaltern subject who faces patriarchy. For the final step, this study will explain how Deeti fights against patriarchy. Then to solve the statement of the problems, some theories above will support to answer, understand and analyze the further meaning among the characters and phenomena in the novel. Those theories will be the references to support this study.

Hence, to analyze this novel into literary work, this study uses deconstruction as the main technique and this is become the first step to explain more about this novel. The next step is collecting the data and will be the purpose of the study. All of the data that have been classified will be analyzed by interpreting it. And this is the third step and also a substantial step in this study. To make this study reliable and understandable the theory from Gayatri Spivak will be used to explain how patriarchy changes the life of the characters in it. Besides, the conclusion will be the final step, to sum up, this study.

\section{Postcolonialism Theory}

The true meaning of postcolonialism is about colonialism, contains of the legend in society, language and landscape. Then the other things are also important to describe postcolonialism studies. It means that the physical area of postcolonial study is wider than any other discipline in literature. Moreover, Spivak mentioned in her critical theory about post-colonial in In Other Worlds: Essays in Cultural Politics (1987) deserves special mention including the essay 'Can the Subaltern Speak?' Spivak widely mentioned the range of subaltern in the works of literature to agglomerate the women. ). While Bhabha argued that colonialism is the set of logical assumptions about the other lands and indigenous people. In his book "The Location of Culture" (1994), Bhabha writes, 'The purpose of colonial discourse is to elaborate the colonized people becomes the dilapidated groups according to their race and cultures, to give the reason to specify the system in colonialism' (Mondal, 2014:2967).

This theory is lead to the orientalist are the 'colonialized subject' that have eccentric and natural behavior. Then the westerner is 'colonializing subject, essentially outside of western culture and civilization. Yet, the discourse of colonialism is trying 
to decrease their radical 'otherness, bringing the inside western understanding through the orientalist project of constructing knowledge about them. A system of 'otherness' is chop of the colonized situation in the deeper meaning of Western knowledge. In Bhabha's perspective, 'colonialism creates the colonized people categorized as a phenomenon that unknown before the other people outside the categorize' (Mondal, 2014:2967).

So, people who categorized as the colonized classified based on the social stereotype which is as a social form to see the poorness of quality from someone. "Stereotyping is not only the setting up of a false image which becomes the scapegoat of discriminatory practices. It is a much more ambivalent text of projection and introjections, metaphoric and metonymic strategies, displacement, guilt, aggressively; the masking and splitting of 'official' and fantastic knowledge'[Bhabha, 1986: 169] (Mondal, 2014:2967).

\section{Subaltern Theory}

The aim of Subaltern is 'lowly people', a name that adopted from Antonio Gramsci to point to the people who are subject to the highest power in society (Ashcroft, Bill Griffiths, Gareth and Tiffin, 2000:198). While Spivak conclude that subaltern is a woman who tried to be assertive in front of other people. She 'spoke' something but women did not, even do not 'hear' her. So, it can be interpreted as a subalter, a subject in society with no power of social movement (Spivak, 2006:28). Then it can be classified into two groups: 'dominant foreign groups' and 'dominant indigenous groups at the all-India and the regional and local levels'. It is the depiction between 'lower classes' and elite people, or on a deeper meaning is 'people' and 'subaltern classes' (Spivak, 2006:32).

Moreover, Guha mentioned that people from politics are classified into the indigenous people. They have authority in politic. In other words, those people are usually the colonials who create the wrong rules for the people outside of their circle. Guha constructs the structure of their position into some places or arrangement. Derrida describes it as an 'antre'. It is the arrangement between the people and the macrostructural dominant groups or as a place of in-betweenness. There are the arrangements of elite people according to Derrida's describing from Guha's statement.

1. Dominant foreign groups.

2. Dominant indigenous groups on the all-India level.

3. Dominant indigenous groups at the regional and local levels.

4. The terms 'people' and 'subaltern classes' (are) used as the terms based on Guha's definition. The social groups and elements included in this category represent the demographic difference between the total Indian population and all those whom that called as the 'elite.'

The historiography from Gramsci has been written down in 'Notes on Italian history'. He was included these outlines for studying the history of the subaltern classes such as: (1) their objective formation; (2) their active or passive affiliation to the dominant political formations; (3) the birth of new parties and dominant groups; (4) the formations that the subaltern groups produce to press their claims; (5) new formations within the old framework that assert the autonomy of the subaltern classes; and other points referring to trade unions and political parties (Gramsci 1971:52) (Ashcroft, Bill Griffiths, Gareth and Tiffin, 2000:198-199). Gramsci agued the history 
of subaltern classes are organized in society. Even they are rebel they cannot detached from the subject of ruling classes. On a deeper meaning, they have less power to control their position, and less access to the higher social classes. But only 'permanent' authority can walk in other levels although they not prevail.

Spivak categorized the subaltern by looking at the situation of gendered subjects and of Indian Women in particular. Both of them are the subject of colonialist historiography and as a subject of insurgency which men as the dominant of the ideological construction. Spivak examines the position of Indian Women through some analysis that sum up and conclude with the declaration that 'the subaltern cannot speak'. The only way they can speak is just to dominant in language, so they can be heard. Unfortunately, that way is difficult to reach that position without through the oppression (Ashcroft, Bill Griffiths, Gareth and Tiffin, 2000:201). Target of Spivak is the problematically subaltern identity not only the subaltern subject's ability to give voice to political concerns. The main point is no act of the resistance occurs on behalf of essential subaltern entirely separate from the dominant discourse that provides the language and the conceptual categories with which the subaltern voice speaks.

\section{Patriarchy}

The term 'patriarchy' was born from the Greek $\pi \alpha \tau \rho i \alpha ́ \rho \chi \eta \varsigma i$ (head of a family who leads the members of it) contains the meaning of authority, family-relationships, and strata in the society (Pierik, 2009:8). Before feminist usage, patriarchy as a concept was mostly used to describe the authority of a father over the household and its members. The history of patriarchy needs 2500 years to complete it into the term of patriarchy. The defintion of patriarchy is about domination of men to women (Lerner, 1986:212). In other words, patriarchy is the concept to overthrow the biological differentiation between men and women, it means women are different because of biological appearance, bodies or even different roles. In this case the notion those men always dominate than women in many ways.

The patriarchal system is marked with power, dominance, competition, and hierarchy. Patriarchal is not only about women's labor but other aspects include sexuality that affects psychology care (Walby, 1990:173). Patriarchy control women from any aspect, especially in sexuality and reproductive capacity. Allan Johnson, a sociologist working in masculinities, calls our male-centered, male-identified, maledominated social structure "patriarchy" and identifies male distrust and fear of other men as patriarchy's core motivating force. Patriarchal culture values "control and domination" most, because the control and domination of other men ensure one's own safety from them. In Allan Johnson's words what drives Patriarchy as a system - what fuels competition, aggression, and oppression - is a dynamic relationship between control and fear. Patriarchy encourages men to seek security, status, and other rewards through control; to fear other men's ability to control and harm them, and to identify being in control as both their best defense against loss and humiliation and the surest route to what they need and desire. In this sense, although we usually think of patriarchy in terms of women and men, it is more about what goes on among men. The oppression of women is certainly an important part of patriarchy, but, paradoxically, it may not be the point of patriarchy (Becker, Beckert, \& Neely, 1999:24).

Although oppression is not the main cause of patriarchy, the social system of masculinity and femininity caused women being treated to fulfill men's needs. This system leads women to a lower position in the social structure. Many forms of groupbased inequality are tangled together in a patriarchal culture. A woman can be a trophy, 
symbolizing and signaling a man's success against and to other men. Most men are not on the top position of hierarchal or patriarchal, because of that women are like the presents for them. This reality gives them little someone over whom they have rights of power and control them as they want to. In patriarchy, women are expected to stay with men when they have been damaged by other men. Besides that, when men are failed, women must be there to accept all of the blame and receive men's disappointment and pain.

\section{DISCUSSION}

\section{The Representation of Subalternity}

To make this point understandable, this study will depict the representation of the subaltern subjects that will be represented by Deeti. Not only that, but the subaltern subject also lives under the patriarchy and this study will discuss how this subject fight against the patriarchy in society. This term was created from Colonialism era that distinguishes the lower and upper class in the society. The whole of this story is telling about the colonized people in their land, but it will represent from the view of Indian Woman called Deeti. She was being a subaltern subject in her life, because her roles, religion, and social structure. This is happening not only because the colonials, but the society also made her became the victim. People thought the colonials are so much must be respected rather than indigenous people. This phenomena creates the patriarchy in the society. It is the term to differentiate people based on their hierarchal strata.

In Sea of Poppies, Deeti as the main character of India women had been alienated from the circumstances which are the submissive of her husband and his family. She had been forced to marry her brother's friend and served her husband's family as a daughter-in-law also a wife. In Deeti's case, her husband's family never showed their respect for her. Like many India families and other India people, caste is the number one in a relationship, including Hukam Singh's family. Deeti was from a lower class than her husband's family and all of the family members are rude to her because of that. The only reason Deeti became Hukam Singh's wife because of Hukam is her brother's friend. Not only have that reasoned, but also as physically Hukam Singh has imperfection legs and only Deeti who wants to marry him. Surprisingly, she found something pathetic on her wedding night that makes her life was changed forever. As a woman who already familiar with the opium, she knew well what she smelled was an opium. She was more believed when he showed her a box of opium that belong to him.

"See-do you know what's in here?

“Afeem naikhe?" She said. "Isn't it opium?” (Ghosh, 2008:19).

Of course, she shocked about the new facts that she never imagined it before. In Spivak's words, the subaltern is a woman who tried to be decisive in extremis. She 'spoke', but women did not, do not, 'hear' her. Thus she can be defined as a 'subalternn', a person without lines of social mobility (Spivak, 2006:28). Deeti is a real representation of the subaltern, she could not speak anything or even asked her husband about something she wonders from. For example, why he could do that to her? Or why did he marry her? What is the reason? She likes the live statue in the human body. She feels anything but her mouth just keeps silent. Her hands just wiped off her tears and pretend to be a happy wife in front of her husband. Even she hates a 
man who likes to consume opium, but she has no option except still being his wife. Deeti is the victim of the patriarchal system in India. She married at her young age without any consideration. India's culture allows its people to marry at a young age. She also married an unknown man and also an opium consumer that makes her felt more disappointed because she knew another lied of her husband.

That circumstance is depicted that Deeti is already being the subaltern from the first time she married with Hukam Singh. Besides that, she was a pure woman who never expected that her life will be so difficult. The main reason is that Deeti is the indigenous people while her husband is the elite people. These strata bring her in the between of confusion where she will be going after she married. Unfortunately, she has to continue and tried to survive in her life under patriarchy. This is another quotation that shows the cheating of Hukam Singh to Deeti. Moreover, her family does not know anything about it, but she could not return because it will violate the culture.

"Did my brother know?" She asked, in a low voice.

"About my pipe?" He laughed. "No; how could he? I only learned to smoke after I was wounded and taken to the hospital barracks. The orderlies there were from the country we were in, Arakan, and when the pain kept us awake at night, they would bring us pipes and show us what to do." (Ghosh, 2008:20).

She and her family were never expected about it, but she can do nothing. It is because of caste, Hukam's family thought that they have more power rather than Deeti's family. So they can do anything to Deeti and her family. This situation depicts the patriarchy in Hukam Singh's family. Hukam Sing as the head of the husband of Deeti has the right to do everything. This includes his lied about the pipe and the reason he could not say it to Deeti's brother. Allan Johnson describes the patriarchy become the form that leads the oppression which causes the fear to others (Becker, Beckert, \& Neely, 1999:24). Hukam Singh gave the aggression to Deeti until she could not says anything because of fear. Deeti afraid of being a widow if she say something wrong and on the other side she afraid her family will get problems because of this.

All of the members of her new family were so rude to her, they had no mercy to Deeti even she was pregnant by her family members. Unfortunately, it was not the daughter of Hukam Singh. Deeti catches the reason for her nickname 'Draupadi' from her mother-in-law and every time she asks why her mother-in-law always said that she had fortune the same as Draupadi who had five husbands and many children. Deeti who called 'Draupadi' by her mother-in-law has the same meaning as the Subaltern. An object that always being submissive, but she survived to live her life in her society. Patriarchal societies are impartial toward men who disregard their obligation as a husband and a head of family rather than impartial toward women who disregard their roles as a wife and mother. Usually those women are failing to be wives and also mothers. It is makes them beliefe that resist against the tradition is difficult (Haj-yahia, 2005:8). Deeti did it not because she wanted to do it, but she must do it. Living with a husband is better than divorce and being a widow. Not a mock from the society that she will get, but she has to find a job to earn money for her and her daughter. Moreover, raising a daughter without a husband is not easy, because she has double duties as a mother and father. So, she chose to receive every bad word from Hukam's family. This system made her become the subaltern subject, she has to ignore every mock from Hukam's family to stay with her husband although Hukam never loves her. Here, the quotation from her mother-in-law who said Deeti likes Draupadi. 
"Because the earth has never seen a more virtuous woman than Draupadi, of the Mahabharata, wife to wife brothers. It's a fortunate woman, a saubhagyawati, who bears the children of brothers for each other ...." (Ghosh, 2008:32).

All of sudden, the conclusion of that question comes up into her mind and the truth is the baby in her belly was not her husband's child, but by Chandan Singh, her leering, slack-jawed brother-in-law. Not only Deeti's curious that already answered, but also the reality about the impotence that suffered by Hukam Singh. It means that he will not have kids. It is shown that Chandan Singh is a father from her daughter. Unfortunately, her mother-in-law tried to preserver her son and abuse Deeti. It seems like the other moms, she always covered everything of her sons. Moreover, she never allowed Deeti to be a happy wife in her marriage. Her mother-in-law did not like her because she thought that Deeti does not deserve all of Hukam's property. She just a poor woman, not beautiful and she is not smart. She thought that Deeti just a baby producer for Hukam Singh.

Hukam Singh is laid up and Deeti had to find the cure to him. She tried to find some works but other people said that she has to sell her property to get money. So she sells her jewels, but Hukam Singh never shows the progress that he will cure his illness. While Deeti still serves him. Sadly, her husband's family is happily waiting for Hukam Singh's death. It is because his wealth that will be owned by his family and Deeti is the only hindrance to get what they want. From all of that realities, Chandan Singh noticed that Hukam Singh will not bear up from his illness, so he tried to tease Deeti in front of Hukam Singh who tried to fight his illness. This grieve reality had written below.

"It's only the truth." He nodded dismissively at his brother's bed. "He couldn't have done it then any more than he can now. It was me; no one else." He added other bad words from his mouth.

"Why not do willingly now what you will be compelled to do a short while hence? Don't you see that I'm offering you your best hope for the future? If you keep me happy, you will be well looked after." (Ghosh, 2008:103-104).

He said everything he did to Deeti, in front of his brother who suffers the death. He offers the advantages if she agrees to be with him because Hukam's property will be owned by him anyway. The sadness is Hukam Singh is dying, not death man. Chandan Singh speaks clearly that he is a jerk. He was the one who raped Deeti on her first wedding night. He also the one who betrayed his brother and wants to get his legacy after his brother dead, but Hukam Singh does not die yet. Chandan Singh is the best jerk ever. It is shown that he tried to mock her because she is a woman from the lower class and he even despised her. Chandan Singh thought Deeti is an easy woman. $\mathrm{He}$ is a bad man, selfish, and rude to everyone including Deeti. Although his brother is bedridden in front of him, he is happy because he will get his wealth. However, Deeti is not an ordinary woman. After she passes her difficult life as Hukam Singh's wife she gets strange to steal her freedom again. She has the bravery to provide herself from Chandan Singh and she decided to avenge him with other jibes because Chandan will never stop to mock her if Deeti still is quiet as usual. She had decided to resist her husband's family to stay at her husband's home. These are the quotation from Deeti and Chandan's conversation. 
"What kind of devil, she said, "can speak like this in front of his dying brother? Listen to my words: I will burn on my husband's pyre rather than give myself to you."

It's not Chandan Sing if his words are good, his answer as bad as him "Words are cheap," he said. "Do you think it's easy for a worthless woman like you to die as a sati? Have you forgotten that your body ceased to be pure on the day of your wedding?"

"Big-big words," he said. "But don't depend on me to stop you, if you try to make yourself a sati. Why should I? To have a sati in the family will make us famous. We'll build a temple for you and grow rich on the offerings. But women like you are all words: when the time comes, you'll escape to your family."

"Dikhatwa! We'll see," Deeti said and lock the door in front of his face (Ghosh, 2008:104).

Spivak's theory about subaltern is focussing on feminism how women live in a society in every aspect such as race, religion, culture, etc. Sati is the representation of Spivak said in the 'Can Subaltern Speak?' to show that some women want to follow their husbands till the end by self-immolation in Sati (Spivak, 1988:93).

The final day of Deeti's life is coming, the cremation was so big because Hukam Singh was a rich man, but the people just want to look Deeti burn herself in pyre with the late Hukam Singh. Fortunately, the kind man Kalua heard that thing, he met with two men who wanted to come to Hukam's cremation. He heard something weird about Sati who will be held in there and he offered to guide them to Hukam Singh's house. The place is so crowded by many people before the cremation, he heard and saw by himself that Deeti will burn her body in Hukam Singh's cremation. Kalua felt so pity because he loved her since they met oftentimes. He decided to safe Deeti and escape from there. Besides, he never had a plan for what he will do after he saves Deeti. Here the quotation that shows how Kalua saves his love.

Racing to the mound, Kalua placed the platform against the fire, scrambled to the top, and snatched Deeti from the flames. On reaching the water, the thrust the platform into the river and placed Deeti upon it. Then, pushing free of the shore, he threw himself flat on the improvised raft and began to kick his heels in the water, steering out towards midstream. All of this was the work of a minute or two and by the time Chandan Singh and his cohorts gave chase, the river had carried Kalua and Deeti away from the flaming pyre, into the dark of the night. (Ghosh, 2008:118-119)

\section{The Struggling to Fight against Patriarchy}

The first step from Deeti to fight the patriarchy was to escape from Hukam's family. She never thought to escape from Sati, but because of Kalua Deeti can run away from that family, at least just for a moment until she knows the next step to face the anger from Hukam's family. Deeti brought shame into Hukam's family. While that family has high self-esteem in society because they are rich people and everyone respects them. So if Deeti walks away from Sati, it means she comes into the hell that made by herself. 
Deeti chose to run and find another place that nobody recognized her and Kalua. She and Kalua keep going to still alive and ran away from their past. In the middle of their journey, they stay in a stranger land. Their confusion brings them into a boat that will take them into a new place. Surprisingly, when they decided to continue the journey and being the immigrants, Deeti heard something about Bhyro Singh, her husband's uncle who always rude to her. The conversations about Bhyro Singh wanted them to die. Here is the conversation that heard by Deeti.

“. . . Stole her from the cremation fire . . . they were seen here together recently, near the Ambaji temple . . . you're of our caste, you understand ..."

"Kya afat-what calamity! It was the kotwal speaking now: What do you want me to do? I'll do anything I can ... tauba . . . tauba ...”

"... Bhyro Singh will pay generously for any help you can offer him ... a as you can understand, the family's honor won't be restored till they're dead ..."

"I'll put the word out, the kotwal promised. If they're here, you can be sure we'll catch them." (Ghosh, 2008:148)

Spivak examines the position of Indian Women through some analysis that sum up and conclude with the declaration that 'the subaltern cannot speak'. The only way they can speak is just to dominant in language, so they can be heard. Unfortunately, that way is difficult to reach that position without through the oppression (Ashcroft, Bill Griffiths, Gareth and Tiffin, 2000:201). This statement is explaining how weak the subaltern's position in society and Kalua realized that. While Deeti chose to fight them with her own ways, no resistance or rebellion but shows them that she can control her fear. She believes that how far she runs, Bhyro Singh is still hunting her and Kalua. So, the better choice is fighting the biggest fear in her life.

The second and last step of Deeti's fighting with her friends is escaping from the Ibis. Ibis is not different from the island. In that ship, she also is the subaltern subject, facing the patriarchy, and surviving the pain because of suppressed. Unfortunately, escape from a big ship like Ibis is not easy. There are a lot of people who always keep an eye to Deeti and her friends in every their moving. So, it needs the best plans to release themselves from the patriarchy in Ibis.

On the other side, Captain Chillingworth tried to speak through his translator Baboo Nob Kissin. This is the speech he spoke to the Girmitiyas.

"... In that direction lies the coast from which you came. In the other lies the sea, known to you like the Black Water. You may think that the difference between the one and the other can be seen clearly with the naked eye. But that is not so. The greatest and most important difference between land and sea is not visible. It is this - and not it well ..."

". . . The difference is that the laws of the land have no hold on the water. At sea, there is another law, and you should know that on this vessel I am its sole maker. While you are on the Ibis and while she is at sea, I am your fate, your providence, your lawgiver. This chabuk you see in my hands is just one of the keepers of my law. But it is not the only one - there is another ..." (Ghosh, 2008:275). 
Through that speech, Captain Chillingworth is serious about his threat. He knew that Girmitiyas were tried to escape from the Ibis. So that is why he pushes them with his scary words that he is the only one who can decide their life in the sea. He did it because of Bhyro Singh told him to do it. Bhyro Singh was the main investor who gave so much income to the captain and Ibis. If Chillingworth was a captain in the Ibis, then Bhyro Sing was a boss that can do anything as he wants. Unfortunately, he is not stopping with that speech, he added some words that more scary to the migrants. Captain Chillingworth has shown that he is the main suspect of patriarchy. Usually, the leader has a duty to protect their members without hurting them, but the Captain does the protection with hurting the innocent immigrants in Ibis just to catch Deeti and Kalua. Patriarchy as a concept was mostly used to describe the authority of a father over the household and its members. Dialect argues that such pre-feminist usage first 'focused on hierarchical relations among men in legal, political, and economic terms (Pierik, 2009:8). Unfortunately, his speech is not finish yet, that speech is written below.

". . . This is the other keeper of the law, and do not doubt for a moment that I will use it without hesitation if it should prove necessary. But remember, always, there is no better keeper of the law that submission and obedience. In that respect, this ship is no different from your own homes and villages. While you are on her, you must obey Subedar Bhyro Singh as you would your zemindars, and as he obeys me. It is he who knows your ways and traditions, and while we are at sea he will be your mái-báp, just as I am his. You should know that it is because of his intercession that no one is being punished today; he has pleaded for mercy on your behalf since you are new to this ship and her rules. But you should know also that the next time there is any disorder on board, the consequences will be severe, and they will be visited upon everyone who plays a part in it; anyone who thinks to make trouble should know that this is what awaits them ... " (Ghosh, 2008:276)

Those speeches gave so much impact to Girmitiyas. Many of the Girmitiyas were in a trance of fear: it was as if they had just woken to the realization that they were not only leaving home and braving the Black Water - they were entering a state of existence in which their waking hours would be ruled by the noose and the whip. (Ghosh, 2008:276).

Then she heard a heavy voice said something to others; "Take the girl away it's the other one I want. I'll talk to her alone."(Ghosh, 2008:329). Surprisingly, that man is Bhyro Singh. Deeti covered his face with Ghungta as usual, but she turned around now to face Bhyro Singh. Here, the conversations between them.

"So?" He said again. "How long did you think you could hide from me, Kabutri-ki-ma?"

"If you knew who I was," she said, "Why didn’t you say something earlier?"

"A bring shame on myself? Acknowledge a tie with a woman like you? A whore who's run away with a filth-sweeper? An overheated bitch who's brought shame on her family, her village, her in-laws? You take me for a fool? Don't you know I have daughters of my own, to marry off?" (Ghosh, 2008:331) 
The classification falls into: 'dominant foreign groups' and 'dominant indigenous groups at the all-India and the regional and local levels'. It is the representation of elite people; in the social groups and elements, or the term of "people" and "subaltern classes" (Spivak, 2006:32). In this case, Bhyro Singh is the member of 'dominant indigenous groups at the all-India and the regional and local levels'. It means that Bhyro's Singh family has the authority in society. Bhyro Singh can do anything to Deeti because he has the power to do that. It will appear in the conversation below.

"Don't you know," he said, "that I'm the one who's in charge of your allotments? Don't you know it's me who decides who your master will be in the Mareech? I've already set your Jora's name down for a plantation up north. He'll never come out from there alive. You can take my word for it: that shit shoveller you call a husband is as good as dead."

He leaned forward so that his belly was against her breasts. He smiled again: Who do you think it was who held your legs open on your wedding night? Did you think that the green twig of a Launda, your brother-in-law, could have done it on his own?" (Ghosh, 2008:331)

One man said the silahdars had already killed Kalua, but some others denied this, saying he was alive, even though he was badly beaten (Ghosh, 2008:340). That Kalua would have to hang for the killing of Bhyro Singh was clear enough, but the news that Kalua would be executed by Bhyro Singh also clear enough in Ibis (Ghosh, 2008:341). Deeti heard that Kalua's execution will be held tomorrow, but she thought that she has not a chance to save Kalua. Before it happens tomorrow, Paulette comes to her to say that she has a plan to release Kalua from the execution.

Patriarchy encourages men to seek security, status, and other rewards through control; to fear other men's ability to control and harm them, and to identify being in control as both their best defense against loss and humiliation and the surest route to what they need and desire. In this sense, although we usually think of patriarchy in terms of women and men, it is more about what goes on among men. The oppression of women is certainly an important part of patriarchy, but, paradoxically, it may not be the point of patriarchy (Becker, Beckert, \& Neely, 1999:24). Indirectly, Bhyro Singh wants to give the fear to Kalua by kidnaped him and then executed him. He felt that killing the people who bring shame to him is not a sin. So, he decided to kill Kalua to make Deeti become a widow. Fortunately, their friends have plans to save Kalua and escape from Bhyro Singh.

Every effort from Neel and Paulette is finally lead them to be free. Ah Fatt had on to his weapon and slamming the door behind him, locked Zachary into the cabin (Ghosh, 2008:355). Zachary locked into the cabin while the girmityas tried to escape from the Ibis. The five girmityas was already ran away as quickly as they could when Serang Ali saw the cabin was already open. The four girmityas was Serang Ali, Jodu, Neel, Ah Fatt, and Kalua. Not longer then Zachary saw three passengers on the boat that he was riding to escape, there was Baboo Nob Kissin, Paulette, and Deeti. At the end, they escaped from the Ibis and chose their ways to truly live life. 


\section{CONCLUSION}

From the findings above, this study has been concluded that Deeti becomes the subaltern subject after she married. In her husband's family, she has to face the patriarchy. Either in her husband's family or in the Ibis. This study finds out that the circumstance around her makes her became the subaltern subject. She is a poor woman, not an intelligent woman, and from the lower class. The main reason for that is because the family patriarchal and social patriarchal that repeatedly Deeti became the submissive in her life. Although she tried to protect herself by escaping from her Sati with Kalua and they became the migrants in the Ibis. Then she got help from her friends who has a similar unfortunate life. Then they left the Ibis to find another better place. These ways are implemented on the system, by using subalterns, oppression, submissive, and patriarchy. Some characters in this novel have their own roles which representation the Subalternity approach by Gayatri Chakravorty Spivak. Most of them are victims that being the subjects who cannot speak what they want.

According to the first statement problems, the first representation of Subalternity is when Deeti being a wife from the rich imperfect man. Her husband's family tortured her, such as rape her, makes her a housekeeper and mocks her with many jibes. Moreover, she had a daughter from her husband's brother after he raped her. Because of that, her mother-in-law called her 'Draupadi' because she had a kid from another man. Unfortunately, like the Draupadi that was accepted her faith by marrying five men, Deeti also accepted her destiny for being a mother from the man she hates the most. However, after she met Kalua she had hopes that she had another chance to love someone she wants. Although Kalua is from the lower classes like her, Deeti feels like she will be a better woman when Kalua around her.

When Chandan Singh mocked her by telling the truth about her wedding marriage, Deeti said something that makes her in a dangerous moment. She challenges Chandan Singh to burn herself with her dying husband when he dies. Deeti knew that was a bad decision, but for her, it was the better choice rather than being a second wife from a man that she hates the most. Then Hukam Singh was finally death, Deeti felt so sad and scared. On the day of Sati a miracle comes to her, Kalua saved her from Sati and he took Deeti into the Ganga River.

After they escaped from their village, they decided to be the immigrants by changing their identities. Deeti replaced her name as Aditi and Kalua as Maru. They both were married in fugitive and Deeti was pregnant. They met Deeti's husband's uncle Bhyro Singh which is the main leader in the land they heading for. But before they arrived in there Bhyro Singh wants to kill them one by one. Amazingly, Deeti and Kalua had some friends who want to escape too. So they help them to be free people without anybody's commands.

The second statement problems show that Indian women also fight the patriarchy that binding them for so long time. Although they are not rebel or resist, in this study, the Indian women are doing something to release from the colonials. From the escapee, he speaks what is on their mind, and leaves the Ibis. It is shown that Indian women are not always quiet when they had tortured by others. But they also can do something, although they still respect their cultures. Because they know that they live with their cultures since they were born and they love the cultures.

Subalternity imposed within the society resulted in two ways. There are refuse the patriarchy and experience the alienation and humiliation. Through Subalternity they show that subaltern is not always a weak people who never can speak for what they belong to. If it is hurt them so much, they will speak to get their own freedom as 
human beings. Also, patriarchy is not the wall that imprisons them from freedom. Patriarchy is just mindset from some people who have more power than others to oppress them. Moreover, the alienation and humiliation that they experience along their life make them got a new strength. They got something to be obtained for the rest of their life.

\section{REFERENCES}

Ashcroft, Bill Griffiths, Gareth and Tiffin, H. (2000). Key Concept of Post-Colonial Studies.

Becker, M., Beckert, M., \& Neely, B. (1999). Patriarchy and Inequality : Towards a Substantive Feminism Substantive Feminism, 1999(1).

Ghosh, A. (2008). Sea of Poppies. Farrar, Straus and Giroux.

Haj-yahia, M. M. (2005). On the Characteristics of Patriarchal Societies , Gender Inequality, and Wife Abuse: The Case of Palestinian Society, 20(November), $1-6$.

Jouzaee, S. A. \& J. L. B. (2014a). Double, 1524-1530.

Jouzaee, S. A. \& J. L. B. (2014b). Double Colonization of Indian Women in Amitav Ghosh's Sea of Poppies. Journal of Novel Applied Sciences, 1524-1530.

Lerner, G. (1986). The Creation of Patriarchy.

Maral, P. (2013). Portrayal of Women in Amitav Ghosh's Sea of Poppies. International Journal of Humanities and Social Science Invention, 2(5), 46-48.

Mondal, A. (2014). Postcolonial Theory : Bhabha and Fanon, 3(11), 2965-2968.

Pierik, B. T. (2009). A History of Patriarchy? MA Thesis for Politics, Philosophy, and Economics. Leiden University, 1-47.

Saumini. (2015). Subaltern Consciousness in Amitav Ghosh's Sea of Poppies, 4(1), 1109-1114.

Sawant, D. G. (2015). Perspectives on Post-colonial Theory: Said , Spivak and Bhabha, (October 2011), 7.

Spivak, G. C. (1988). Can the Subaltern Speak? Marxism and the Interpretation of Culture, Macmillan: Basingstoke, 1988, Pp. 271-313. Retrieved from http://www.mcgill.ca/files/crclaw-discourse/Can_the_subaltern_speak.pdf

Spivak, G. C. (2006). Can the Subaltern Speak [1988]. The Post Colonial Studies Reader, 271-313.

Sultana, A. (2011). Patriarchy and W omen's Subordination : A Theoretical Analysis, $1-18$.

Tyagi, P., Pradesh, U., \& Pradesh, U. (2018a). Amitav Ghosh's sea of poppies : A feminist perspective, 141-143.

Tyagi, P., Pradesh, U., \& Pradesh, U. (2018b). Amitav Ghosh's sea of poppies : A feminist perspective, 141-143.

Walby, S. (1990). Theorizing Patriarchy - Sylvia Walby.pdf. 